\title{
Post-Mortem Immunohistochemical Evidence of B2-Adrenergic Receptor Expression in the Adrenal Gland
}

\author{
Elvira Ventura Spagnolo ${ }^{1, *}$, Cristina Mondello ${ }^{2, *}$, Luigi Cardia ${ }^{3}{ }^{(\mathbb{C}}$, Letteria Minutoli ${ }^{4}$, \\ Domenico Puzzolo ${ }^{2}{ }^{\oplus}$, Alessio Asmundo ${ }^{2}$, Vincenzo Macaione ${ }^{4}$, Angela Alibrandi ${ }^{5}$, \\ Consuelo Malta ${ }^{2}$, Gennaro Baldino ${ }^{1}$ and Antonio Micali ${ }^{2}$
}

1 Legal Medicine Section, Department for Health Promotion and Mother-Child Care, University of Palermo, Via del Vespro, 129, 90127 Palermo, Italy; gennarobld@hotmail.it

2 Department of Biomedical and Dental Sciences and Morphofunctional Imaging, University of Messina, via Consolare Valeria, 1, 98125 Messina, Italy; puzzolo@unime.it (D.P.); aasmundo@unime.it (A.A.); consuelo_malta@hotmail.it (C.M.); amicali@unime.it (A.M.)

3 Department of Human Pathology of Adult and Childhood "Gaetano Barresi", University of Messina, Via Consolare Valeria, 98125 Gazzi, Italy; luigicardia1@gmail.com

4 Department of Clinical and Experimental Medicine, University of Messina, via Consolare Valeria, 1, 98125 Messina, Italy; Iminutoli@unime.it (L.M.); vmacaione@unime.it (V.M.)

5 Department of Economics, Unit of Statistical and Mathematical Sciences, University of Messina, Via dei Verdi 75, 98122 Messina, Italy; aalibrandi@unime.it

* Correspondence: elvira.ventura@unipa.it (E.V.S.); mondelloc@unime.it (C.M.); Tel.: +39-3496465532 (E.V.S.); +39-3477062414 (C.M.)

Received: 6 June 2019; Accepted: 20 June 2019; Published: 23 June 2019

\begin{abstract}
The evidence from post-mortem biochemical studies conducted on cortisol and catecholamines suggest that analysis of the adrenal gland could provide useful information about its role in human pathophysiology and the stress response. Authors designed an immunohistochemical study on the expression of the adrenal $\beta 2$-adrenergic receptor ( $\beta 2-A R)$, a receptor with high-affinity for catecholamines, with the aim to show which zones it is expressed in and how its expression differs in relation to the cause of death. The immunohistochemical study was performed on adrenal glands obtained from 48 forensic autopsies of subjects that died as a result of different pathogenic mechanisms using a mouse monoclonal $\beta 2$-AR antibody. The results show that immunoreactivity for $\beta 2$-AR was observed in all adrenal zones. Furthermore, immunoreactivity for $\beta 2$-AR has shown variation in the localization and intensity of different patterns in relation to the original cause of death. To the best of our knowledge, this is the first study that demonstrates $\beta 2$-AR expression in the human cortex and provides suggestions on the possible involvement of $\beta 2$-AR in human cortex hormonal stimulation. In conclusion, the authors provide a possible explanation for the observed differences in expression in relation to the cause of death.
\end{abstract}

Keywords: adrenal gland; $\beta 2$-adrenergic receptors; immunohistochemistry; post-mortem analysis

\section{Introduction}

The adrenal response to stress involves the activation of the sympathoadrenal (SA) system and the hypothalamic-pituitary-adrenocortical (HPA) axis; in this way, homeostasis in emergencies such as "fight or flight" situations is maintained [1]. Several studies were performed to explain the activities of these mechanisms and it was demonstrated that the stress response activates the sympathetic nervous system (SNS) and the subsequent release of catecholamines from the sympathetic nervous system 
terminals and the adrenal glands [2]. However, scientific evidence has shown that both the SNS and the adrenomedullary system can respond differentially to stress in relation to the type and the intensity of the stressor and to the perception and interpretation of the stress situation [3]. In this setting, the adrenomedullary secretion was also associated with the concurrent activation of the HPA axis [4].

In the forensic field, many researchers analyzed the individual differences in the stress response during the death process, mostly investigating both catecholamine and glucocorticosteroid levels, using a biochemical approach [5-8] and immunohistochemistry [9]. Nevertheless, catecholamines have been considered as an unstable marker in the post-mortem investigation of the causes or the process of death [5]. Moreover, very few studies in forensic pathology have been carried on the adrenal gland, despite it being one of the main organs involved in the stress response, releasing corticosteroids and catecholamines $[10,11]$. Catecholamines are able to up-regulate the expression of membrane-bound proteins known as adrenergic receptors (ARs), and the $\beta 2$-AR pathway, in many organs, either in normal [12] or in pathological conditions [13,14], suggesting that the analysis of the molecular change of such receptors could provide information on specific circumstances related to stressful events.

ARs are cell membrane receptors included in the seven-transmembrane-spanning G-protein coupled receptor (GPCR) superfamily, formed by membrane proteins triggered by extracellular ligands such as small organic molecules, peptides, and neurotransmitters [15]. Structurally, GPCRs are formed by seven hydrophobic transmembrane segments which cross the plasma membrane with an extracellular amino terminus and an intracellular carboxyl-terminus. Intracellularly, GPCRs interact with $G$ proteins, which induce the stimulation of numerous targets [16-18]. ARs mediate the action of the sympathetic neurotransmitter noradrenaline and the hormone adrenaline, even if some are of higher affinity to the former molecule [19].

According to their pharmacological response, ARs were subdivided into $\alpha$ and $\beta$ types: these latter types were further divided into three families called $\beta 1, \beta 2$ and $\beta 3$ on the basis of molecular classification $[19,20]$. $\beta 2$-ARs have been described in multiple locations such as the lung, heart, blood vessels, and nasal turbinates $[13,15,20]$. However, there is little data available on the presence of $\beta 2$-ARs in the adrenal gland. In isolated adrenal chromaffin cells, the presence of $\beta 2$-ARs was demonstrated both in rats [21] and in humans [22], suggesting that, at least in vitro, catecholamine release could be modulated by the activation of $\beta 2$-ARs. Furthermore, in primary cultures of cells from the fasciculata and the reticularis zones of the bovine adrenal gland, the presence of $\beta 2$-ARs was demonstrated [23].

The purpose of this study was to analyze the adrenal glands obtained from forensic autopsies in order to evaluate the expression of $\beta 2-\mathrm{AR}$ in the adrenal glands and to investigate its expression in subjects with different causes of death.

\section{Results}

The study revealed an evident immunoreactivity for $\beta 2$-AR expressed in the human adrenal gland (glomerulosa, fasciculata, reticularis and medulla zones) (Figures 1 and 2).

Moreover, the positive staining varied in localization and intensity in the specimens obtained from subjects included in the six groups examined, as shown in Table 1:

- hanging: the immunostaining of $\beta 2-\mathrm{AR}$ was higher in the glomerulosa, reticularis, and medulla (Figure 1a,c,d), while a lower expression was observed in the fasciculata (Figure 1b). The statistical analysis confirmed the significant differences among the zones $(p<0.05$ versus the fasciculata zone) (Figure 1e);

- drowning: the $32-A R$ immunostaining was higher in the glomerulosa and the medulla (Figure 1f,i), and significantly lower in the fasciculata and in the reticularis (Figure 1g,h). The statistical analysis also showed significant differences $(p<0.05)$ between the glomerulosa and the medulla (Figure 1j).

- fire fatality: the fasciculata and the reticularis zones (Figure $11, \mathrm{~m}$ ) were significantly positive for $\beta 2$-AR when compared to the other zones (Figure $1 \mathrm{k}, \mathrm{n}$ ). In these cases, a significant difference was also observed between the fasciculata and the reticularis $(p<0.05)$ (Figure 1o); 
- road accident: if compared to the other adrenal zones (Figure $2 \mathrm{a}, \mathrm{b}, \mathrm{d}$ ), only the reticularis (Figure $2 \mathrm{c}$ ) showed evident $\beta 2$-AR immunostaining, which was also confirmed by the statistical analysis (Figure 2e);

- $\quad$ sudden cardiac death: the glomerulosa and the medulla showed mild $\beta 2-A R$ immunostaining (Figure 2f,i), while the fasciculata (Figure 2g,j) was significantly positive for $\beta 2$-AR; the reticularis was negative (Figure $2 \mathrm{~h}$ ).

- $\quad$ sepsis: the highest $32-\mathrm{AR}$ immunostaining was observed in the glomerulosa (Figure 2k); the positivity in the reticularis was less evident (Figure $2 \mathrm{~m}$ ), but significantly higher than in the fasciculata and the medulla (Figure 21,n,o).

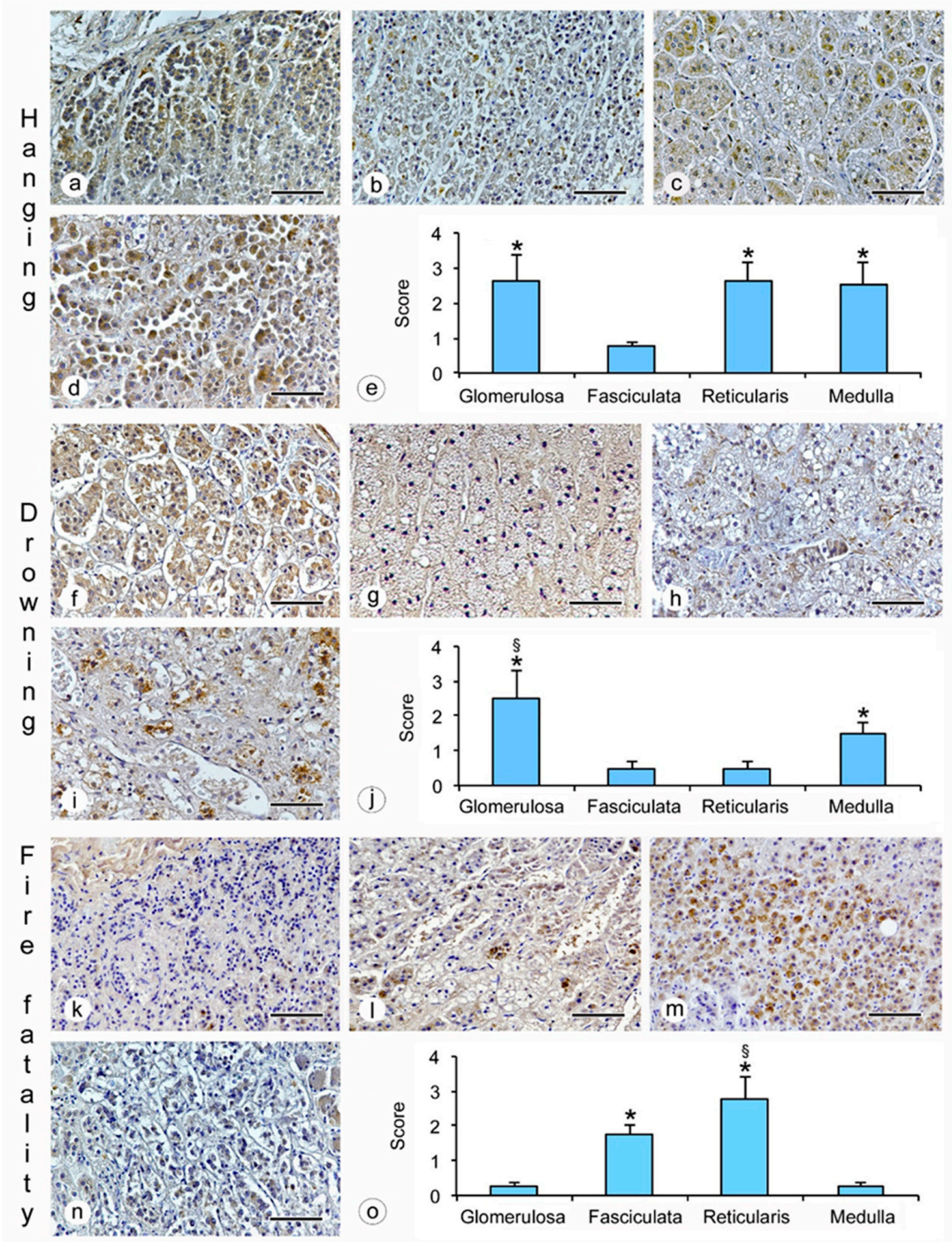

Figure 1. $\beta 2-\mathrm{AR}$ expression in cases of hanging, drowning and fire fatality in the different zones of the adrenal gland. $\mathbf{a}, \mathbf{f}, \mathbf{k}=$ glomerulosa zone; $\mathbf{b}, \mathbf{g}, \mathbf{l}=$ fasciculata zone; $c, h, m=$ reticularis zone; $\mathbf{d}, \mathbf{i}, \mathbf{n}=$ medulla; $\mathbf{e}=$ levels of immunohistochemical expression in the different zones of the adrenal gland of subjects from the hanging group based on the arbitrary score used. ${ }^{*}=p<0.05$ versus fasciculata zone; $\mathbf{j}=$ levels of immunohistochemical expression in the different zones of the adrenal gland of subjects from the drowning group based on the arbitrary score used. ${ }^{*}=p<0.05$ versus glomerulosa zone and medulla, $\S=p<0.05$ versus medulla; $\mathbf{o}=$ levels of immunohistochemical expression in the different zones of the adrenal gland of subjects from the fire fatality group based on the arbitrary score used. ${ }^{*}=p<0.05$ versus glomerulosa zone and medulla, $\S=p<0.05$ versus fasciculata zone. (Scale bar $=100 \mu \mathrm{m})$. 

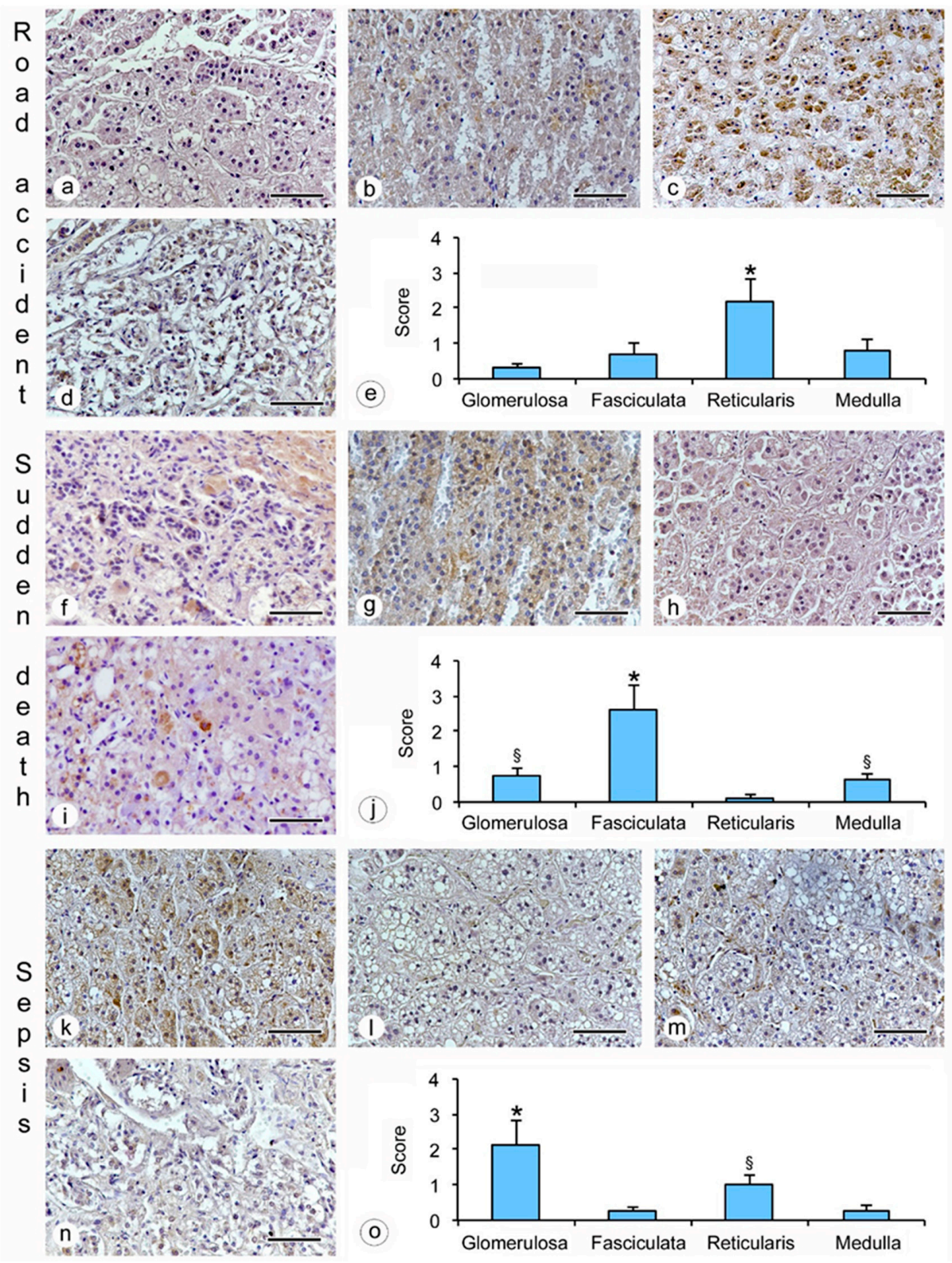

Figure 2. $\beta 2$-adrenergic receptor (AR) expression in cases of road accidents, sudden death and sepsis in the different zones of the adrenal gland. $\mathbf{a}, \mathbf{f}, \mathbf{k}=$ glomerulosa zone; $\mathbf{b}, \mathbf{g}, \mathbf{l}=$ fasciculata zone; $\mathbf{c}, \mathbf{h}, \mathbf{m}=$ reticularis zone; $\mathbf{d}, \mathbf{i}, \mathbf{n}=$ medulla; $\mathbf{e}=$ levels of immunohistochemical expression in the different zones of the adrenal gland of subjects from the road accident group based on the arbitrary score used. $*=p<0.05$ versus glomerulosa and fasciculata zones and medulla; $\mathbf{j}=$ levels of immunohistochemical expression in the different zones of the adrenal gland of subjects from the sudden death group based on the arbitrary score used. ${ }^{*}=p<0.05$ versus glomerulosa and reticularis zones and medulla, $\S=p<0.05$ versus reticularis zone; $\mathrm{o}=$ levels of immunohistochemical expression in the different zones of the adrenal gland of subjects from the sepsis group based on the arbitrary score used. ${ }^{*}=p<0.05$ versus fasciculata and reticularis zones and medulla, $\S=p<0.05$ versus fasciculata zone and medulla. Scale bar $=100 \mu \mathrm{m}$.

As a consequence of the above results, the comparison between $\beta 2$-AR expression in the single zones showed that: (a) the glomerulosa zone has a higher expression in hanging, drowning and sepsis deaths; (b) the fasciculata zone was significantly positive in sudden cardiac death and fire fatalities; 
(c) the reticularis zone shows a higher $\beta 2$-AR expression in hanging, fire fatalities, and road accidents;

(d) medulla expression was greater in cases of hanging and drowning (Figure 3 ).
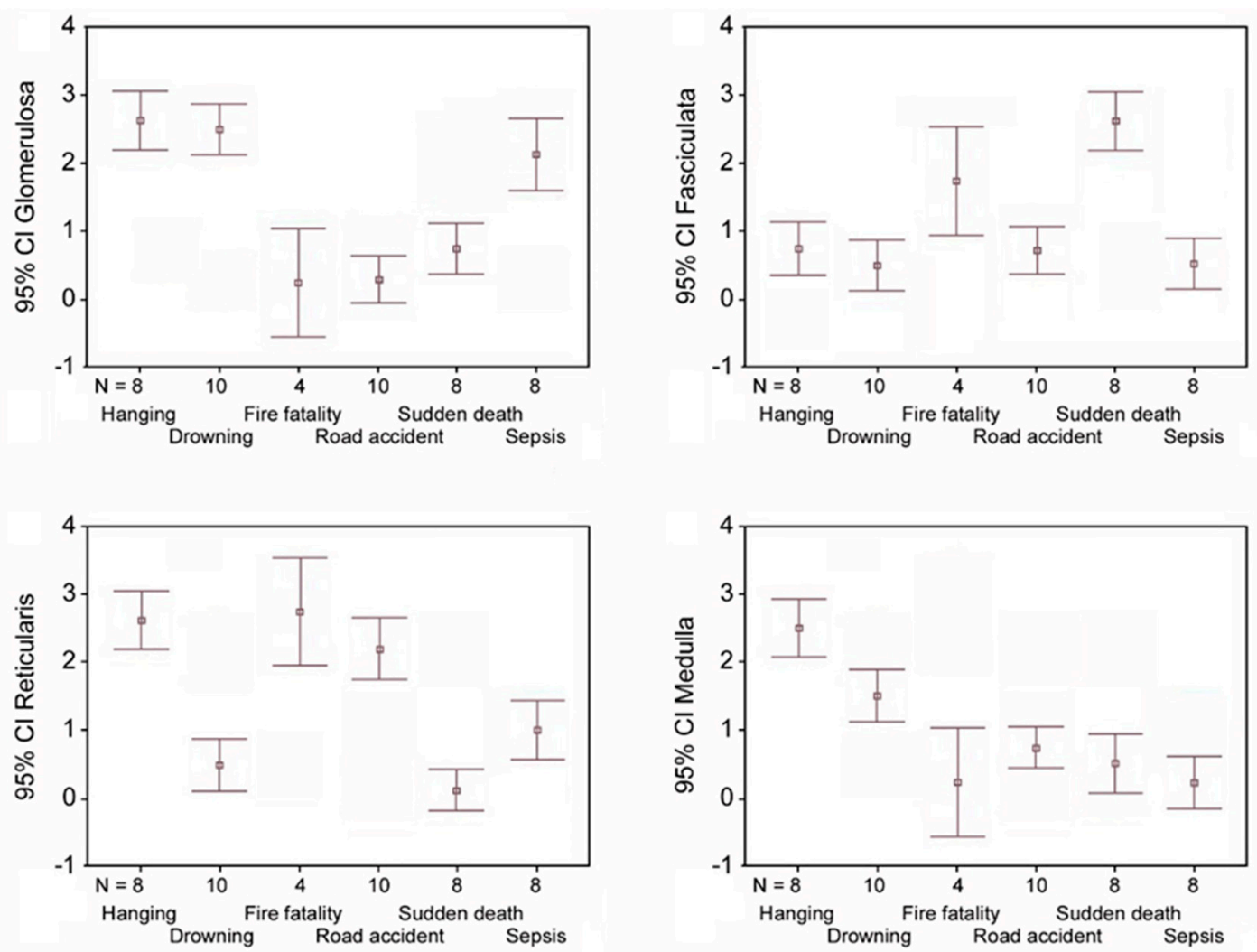

Figure 3. Error bar graphs show mean value and relative $95 \%$ confidence interval (CI) of $\beta 2-A R$ expression of each adrenal zone (glomerulosa, fasciculata, reticularis, medulla) in the different causes of death examined.

\section{Discussion}

The aim of this study was to analyze the structural and/or molecular changes in adrenal glands obtained from forensic autopsies of different causes of death, in order to evaluate the presence of $\beta 2$-AR in the four zones of the glands and to investigate its expression in subjects that died during different stressful conditions. In particular, the study was directed to analyze an adrenal tissue marker involved in the stress response process to activated/stimulated receptors by the activation of the SA system and HPA axis, focalizing the attention exclusively on the adrenal gland and its specific functions.

The study showed that $\beta 2$-ARs were expressed in the human medulla and cortex and that cortical expression was observed in all zones, suggesting that in the stress response, the adrenergic system could contribute, as a complementary pathway, to stimulate steroid production and release involving the glomerulosa, the fasciculata and the reticularis, respectively secreting mineralocorticoids, glucocorticoids and androgens [24]. While the involvement of glucocorticoids and catecholamines in the stress response is well described, few studies examine the hormones secreted from the glomerulosa and reticularis, which are regulated by adrenocorticotropic hormone (ACTH) [25]. Therefore, to the best of our knowledge, the present study is the first:

(i) to histologically demonstrate $\beta 2$-AR expression in the human cortex;

(ii) to provide suggestions on the possible involvement of $\beta 2-\mathrm{AR}$ in human cortex hormonal stimulation, and

(iii) to study $\beta 2$-AR expression in the adrenal gland in different causes of death. 
The presence of $\beta 2-\mathrm{AR}$ in the cortical zone of the human adrenal gland might indicate that the cortex and medulla, even if embryologically different, could share common mechanisms in the coordination of the stress response.

As to the possible involvement of $\beta 2$-AR in human cortex hormonal stimulation, the results have demonstrated that an in vivo cross-talk between cortical and medullary cells was present according to previous evidence based on vascular and nervous adrenal features. Adrenomedullary cells receive blood from the cortex in which high concentrations of adrenocortical steroids are present [3] and cortical nerves derived from the sympathoadrenal cell lineage are organized in an intricate plexus in the subcapsular region which extends into the fasciculata and reticularis layers [26-29]. Thus, the reported findings confirm the importance of medullary-cortical interactions and the role of the sympathoadrenal system and catecholamines when stress occurs. The presence of $\beta 2$-ARs in all the cellular layers of the adrenal cortex represents the morphological basis to explain the existence (in addition to ACTH release) of paracrine regulation of adrenocortical steroidogenesis from medullary cells [30]. In fact, it was observed that the perfusion of the isolated porcine adrenal glands with epinephrine or norepinephrine induced the secretion of cortisol, aldosterone, and androstenedione [30]. Therefore, the results of the immunohistochemical localization of $\beta 2$-ARs could represent the morphological prerequisites for an intra-adrenal regulatory interaction during the stress response.

Moreover, the study showed differing $\beta 2$-AR expression, for both localization and quantity, in the adrenal glands of subjects who died from different causes, suggesting that the activation/stimulation of adrenergic receptors might vary on the basis of different stressful conditions related to the death process.

Although many studies have highlighted the increase of catecholamines and glucocorticoids in relation to stress $[3,6]$, the findings of our study documented the involvement of the whole gland: the glomerulosa and reticularis were also stimulated together with the fasciculata and medulla layers. It was interesting to discover that in some causes of death, the expression of the receptors appeared predominant in these other two zones; in fact, only sudden cardiac death and hanging showed a greater expression of $\beta 2$-AR respectively in the fasciculata and medulla.

In the sudden cardiac death group, the greater expression in the fasciculata suggested that the adrenal gland response could be mainly associated with the synthesis and secretion of glucocorticoids, possibly related to their effect on blood pressure regulation and on evidence suggesting the involvement in heart rate control by the arterial baroreceptor reflex [31-33].

In the hanging group, the asphyxia condition could induce a greater stimulation of medullary $\beta 2$-ARs to promote the synthesis and secretion of catecholamines as supported by evidence on adrenalin and noradrenaline increase due to both blood $\mathrm{pH}$ alteration induced by hypoxia and activation of a sympathetic-adrenal mechanism regulating the cardiovascular response to asphyxia (redistribution of blood flow toward the brain and muscle beds). In previous experimental studies on the analysis of the effects of asphyxia, an increase of systemic arterial pressure, sympathetic vertebral nerve activity, nitric oxide formation and the release of plasma catecholamine components of norepinephrine and epinephrine was observed [34,35]; moreover post-mortem biochemical analysis on blood from subjects that died of asphyxiation revealed high levels of adrenalin [7]. The coexistence of $\beta 2-\mathrm{AR}$ overexpression in the glomerulosa and reticularis could be related to the described neuroprotective effects of mineralcorticoids and dehydroepiandrosterone (DHEA), considering that the mechanisms of death in hanging are generally vagal inhibition and/or asphyxia and/or cerebral ischemia and/or cerebral congestion [36]. Some researchers have shown an increase in mineralcorticoid receptors in specific cerebral areas (i.e., the hippocampus) after asphyxia, supporting the substantial role of corticoids in the neural response to conditions of oxidative stress and ischemia/hypoxia, even if the mediated neuronal mechanism remains unclear [37]. The neurotrophic and/or neuroprotective activity in the central nervous system was observed also for DHEA on the basis of strong evidence, suggesting its effects on GABAergic transmission modulation in the central nervous system [38,39]. 
In the road accident group, including subjects with brain injuries, the effects of DHEA and DHEA sulfate (DHEAS) could explain the higher $\beta 2$-AR expression observed in the reticularis zone, as these hormones have positive effects in brain lesions as documented by experimental studies [40,41].

In the fire fatality group, the significant $\beta 2$-AR expression in the reticularis could be related to the modulation of the nociceptive function of DHEA and DHEAS [42,43], in particular in three of our subjects who died quickly from severe burns and, possibly, in intense painful conditions.

In the sepsis group, the higher $\beta 2$-AR expression in the glomerulosa suggested a role for mineralocorticoid synthesis and secretion, related to compensatory mechanisms activated to increase volemia and arterial blood pressure through the renin-angiotensin-aldosterone system (RAAS) [44,45]. It is well known that the activation of the RAAS is part of an intrinsic neuroendocrine response to sepsis-related circulatory failure also mediated by the activation of the hypothalamic-pituitary-adrenal axis $[46,47]$.

In the drowning group, the higher expression of $\beta 2-A R$ in the glomerulosa is possibly related to the systemic effects of drowning fluid. Studies on pathophysiology highlighted that drowning determines different systemic responses and outcomes, in relation to immersion (upper airway above water) and/or submersion (upper airway under water), depending also on the characteristics of the drowning liquid (i.e., temperature and osmolarity). These systemic effects affect the cardiocirculatory, respiratory and neural systems by several mechanisms, mediated by hypothermia, hypovolemia, diving response, autonomic conflict, upper airway reflexes, water aspiration and swallowing, and electrolyte disorders $[48,49]$. In light of this, on the basis of the results of the present study, it could be supposed that there is a role for mineralcorticoids in reacting to drowning-related phenomena to cause hypovolemia and electrolyte modifications.

Therefore, the present study highlights the post-mortem profile of $\beta 2$-AR expression in the human adrenal gland, showing topographic and quantitative differences, possibly related to different causes of death. These results suggest that other studies aiming to evaluate the correlation between adrenal $\beta 2-\mathrm{AR}$ expression and the activation of SA system and HPA axis (not investigated in the present study) could be very useful to improve the knowledge of stress response processes. Furthermore, in a medicolegal approach to the causes and mechanisms of death, adrenal gland analysis could prove to be, as well as other second level investigations [50-56], a useful tool to improve the etiopathogenetic assessment of stress-related death.

The major limits of our study are represented by the relatively small number of samples and by the possible influence on $\beta 2$-ARs expression caused by the subject's previous pharmacological therapy (data not known). Furthermore, post-mortem changes cannot be evaluated in this study, thus no comments can be offered on the effects of post-mortem phenomena on receptor expression. The authors did not analyze the relationship between the obtained results and other factors (age and sex, agony duration), which would also possibly affect the expression of the receptors.

\section{Materials and Methods}

Forty-eight forensic autopsies, carried out between March 2017 and December 2017, were included in this study (Table 1). The following causes of death were included: (i) hanging ( $n=8 ; 3$ females and 5 males; mean age $51.4 \pm 17$ years); (ii) road accident ( $n=10 ; 6$ women and 4 men; mean age $56.3 \pm 23.6$ years); (iii) fire fatality ( $n=4 ; 1$ woman and 3 men; mean age $46.3 \pm 22.9$ ); (iv) sudden cardiac death ( $n=8 ; 2$ women and 6 men; mean age $52.7 \pm 16.9$ years); (v) sepsis ( $n=8,6$ women and 2 men; mean age $67.4 \pm 10.7$ years); and (vi) drowning ( $n=10 ; 3$ women and 7 men; mean age $28.5 \pm 15.3$ years). All autopsies were performed $24-48 \mathrm{~h}$ after death.

This is a retrospective study carried out on filed judiciary cases in which the specimens were taken during autopsy as ordered by a judicial authority. The authors asked for ethical approval (prot. $\mathrm{n}$. 24/19, 28/2/2019) from the Local Ethics Committee (Comitato Etico Interaziendale della Provincia di Messina) that declared no-competence because the study used judiciary specimens. The authors got the permission to use the autopsy samples for research purposes by the General Public Prosecutor. 
Table 1. Age, sex, cause of death, adrenal cortical scores and adrenal medullary scores in the case series.

\begin{tabular}{|c|c|c|c|c|c|c|c|}
\hline & & & & & Cortex & & Medulla \\
\hline Case & Age & Sex & Cause of Death & Glomerulosa & Fasciculata & Reticularis & \\
\hline 1 & 53 & F & Hanging & 3 & 1 & 3 & 3 \\
\hline 2 & 44 & $\mathrm{~F}$ & & 3 & 1 & 3 & 3 \\
\hline 3 & 57 & F & & 2 & 1 & 2 & 2 \\
\hline 4 & 38 & $\mathrm{M}$ & & 3 & 0 & 2 & 3 \\
\hline 5 & 66 & $\mathrm{M}$ & & 3 & 1 & 3 & 2 \\
\hline 6 & 70 & $\mathrm{M}$ & & 2 & 0 & 2 & 2 \\
\hline 7 & 64 & $\mathrm{M}$ & & 3 & 1 & 3 & 3 \\
\hline 8 & 19 & $\mathrm{M}$ & & 2 & 1 & 3 & 2 \\
\hline 9 & 79 & $\mathrm{M}$ & Road accident & 0 & 1 & 2 & 1 \\
\hline 10 & 73 & $\mathrm{M}$ & & 0 & 1 & 2 & 1 \\
\hline 11 & 23 & $\mathrm{M}$ & & 1 & 0 & 3 & 1 \\
\hline 12 & 30 & F & & 0 & 0 & 2 & 0 \\
\hline 13 & 66 & $\mathrm{~F}$ & & 0 & 1 & 1 & 1 \\
\hline 14 & 58 & F & & 1 & 1 & 2 & 0 \\
\hline 15 & 19 & $\mathrm{M}$ & & 1 & 1 & 3 & 1 \\
\hline 16 & 80 & F & & 0 & 0 & 2 & 1 \\
\hline 17 & 75 & $\mathrm{~F}$ & & 0 & 1 & 3 & 1 \\
\hline 18 & 60 & F & & 0 & 1 & 2 & 1 \\
\hline 19 & 19 & $\mathrm{M}$ & Fire fatality & 0 & 2 & 3 & 0 \\
\hline 20 & 52 & $\mathrm{M}$ & & 0 & 2 & 3 & 0 \\
\hline 21 & 74 & $\mathrm{M}$ & & 1 & 2 & 2 & 1 \\
\hline 22 & 40 & F & & 0 & 1 & 3 & 0 \\
\hline 23 & 33 & $\mathrm{~F}$ & Sudden death & 1 & 3 & 0 & 1 \\
\hline 24 & 27 & $\mathrm{M}$ & & 1 & 3 & 0 & 1 \\
\hline 25 & 61 & $\mathrm{M}$ & & 0 & 2 & 0 & 0 \\
\hline 26 & 63 & $\mathrm{~F}$ & & 1 & 2 & 1 & 1 \\
\hline 27 & 68 & $\mathrm{M}$ & & 0 & 3 & 0 & 0 \\
\hline 28 & 56 & $\mathrm{M}$ & & 1 & 2 & 0 & 1 \\
\hline 29 & 41 & $\mathrm{M}$ & & 1 & 3 & 0 & 0 \\
\hline 30 & 73 & $\mathrm{M}$ & & 1 & 3 & 0 & 1 \\
\hline 31 & 67 & $\mathrm{~F}$ & Sepsis & 2 & 0 & 1 & 0 \\
\hline 32 & 82 & $\mathrm{~F}$ & & 2 & 0 & 1 & 0 \\
\hline 33 & 62 & $\mathrm{M}$ & & 1 & 0 & 1 & 0 \\
\hline 34 & 72 & F & & 3 & 0 & 1 & 1 \\
\hline 35 & 74 & $\mathrm{M}$ & & 2 & 0 & 0 & 0 \\
\hline 36 & 54 & $F$ & & 3 & 1 & 2 & 1 \\
\hline 37 & 76 & F & & 2 & 0 & 1 & 0 \\
\hline 38 & 52 & F & & 2 & 1 & 1 & 0 \\
\hline 39 & 18 & $\mathrm{M}$ & Drowning & 3 & 1 & 1 & 2 \\
\hline 40 & 21 & $\mathrm{M}$ & & 2 & 0 & 0 & 1 \\
\hline 41 & 18 & $\mathrm{M}$ & & 3 & 0 & 1 & 2 \\
\hline 42 & 23 & $F$ & & 2 & 1 & 1 & 1 \\
\hline 43 & 58 & $\mathrm{M}$ & & 3 & 0 & 1 & 2 \\
\hline 44 & 53 & $F$ & & 2 & 1 & 0 & 2 \\
\hline 45 & 18 & F & & 3 & 0 & 1 & 1 \\
\hline 46 & 22 & $\mathrm{M}$ & & 2 & 1 & 0 & 2 \\
\hline 47 & 18 & $\mathrm{M}$ & & 2 & 0 & 0 & 1 \\
\hline 48 & 36 & $\mathrm{M}$ & & 3 & 1 & 0 & 1 \\
\hline
\end{tabular}




\subsection{Immunohistochemistry Analysis}

Adrenal glands obtained from the above autopsies were fixed in $4 \%$ paraformaldehyde in $0.2 \mathrm{M}$ phosphate buffered saline (PBS), dehydrated in graded ethanol, cleared in xylene and embedded in paraffin (Paraplast, SPI Supplies, West Chester, PA, USA). The histological sections (5 $\mu \mathrm{m})$ were deparaffinized in xylene and rehydrated in ethanol. Antigen retrieval was performed with $\mathrm{pH} 6.0$ citrate buffer and endogenous peroxidase blocked with $0.3 \% \mathrm{H}_{2} \mathrm{O}_{2}$ in PBS. The primary antibody ( $\beta 2$-AR, Santa Cruz, Dallas, TX, USA; $1 / 100$ dilution) was incubated overnight at $4{ }^{\circ} \mathrm{C}$ in a moisturized chamber. The following day, peroxidase-conjugated secondary antibody (Pierce anti-rabbit, anti-goat, and anti-mouse, Cambridge, UK; 1/50 dilution) was added and the reaction was visualized with 3,3'-diaminobenzidine (DAB) (Sigma-Aldrich, Milan, Italy). Counterstaining was performed in Mayer's hematoxylin (alum hematoxylin). Negative controls from all the regions of the adrenal gland (glomerulosa, fasciculata, reticularis and medulla) were obtained using PBS instead of the primary antibody (supplementary materials). For the positive control, normal human pancreas sections were used according to the manufacturer's instructions.

\subsection{Morphometric Analysis}

The sections were photographed with a Nikon Ci-L (Nikon Instruments, Tokyo, Japan) light microscope. All images were taken with a digital camera (Nikon Ds-Ri2) and saved as Tagged Image Format Files (TIFF) with the Adobe Photoshop CS software. Five randomly chosen microscopic fields (MFs) from five non-serial sections of each group were considered. All micrographs were captured at the same magnification and were blindly assessed by two trained observers who ignored which of the groups the examined specimens belonged to. Immunopositivity of $\beta 2$-AR in each zone of the adrenal gland (glomerulosa, fasciculata, reticularis and medulla) was graded according to the following semi-quantitative score: 0 , negative; 1 , slight and/or limited (to a few groups of cells) positivity; 2 , patchy and scattered positivity; 3 , diffuse and intense positivity.

\subsection{Statistical Analysis}

For each cause of death, data referring to the semi-quantitative grading of $\beta 2$-AR expression assigned to the different zones of all glands were expressed as mean \pm standard deviation (SD). A non-parametric approach was used since the examined variables were not normally distributed, as verified by the Kolmogorov-Smirnov test. For each cause of death, a non-parametric ANOVA was applied in order to assess the existence of possible differences among the four adrenal gland zones (intra-groups analysis). The same analysis was performed in order to assess, for each zone, possible differences among the six causes of death (inter-groups analysis). Statistical analysis was performed using the SPSS 17.0 for Window package. A $p$-value of $\leq 0.05$ was considered statistically significant.

\section{Conclusions}

This study revealed the expression of $\beta 2$-ARs in all layers of the human adrenal gland and supports the presence of a cross-talk between cortical and medullary cells.

The obtained results suggest, also, that the adrenal gland could respond to stress with a kind of "specificity", managing homeostatic changes determined by different stressors and stressful conditions, possibly providing a specific response in different death processes.

The authors state that, considering the poor literature about adrenal gland $\beta 2$-ARs and the absence of previous studies focused on adrenal gland functional changes during death processes, the obtained results must be considered as preliminary evidence supporting the opportunity to perform further research aimed to improve the knowledge of the adrenal gland's functionalities and to discover its role in human pathophysiology during stress conditions.

Supplementary Materials: The supplementary materials are available online at http://www.mdpi.com/1422-0067/ 20/12/3065/s1. Representative images of positive and negative controls are reported in the supplementary materials. 
Author Contributions: conceptualization, E.V.S., C.M. (Cristina Mondello), D.P., L.C. and A.M.; methodology, D.P., A.M. and L.M.; formal analysis, A.A. (Alessio Asmundo) and C.M. (Consuelo Malta); investigation, E.V.S., D.P., A.M. and C.M. (Consuelo Malta); resources, E.V.S., C.M., A.M., D.P., V.M., A.A. (Angela Alibrandi), and G.B.; data curation, D.P., A.M. and A.A. (Angela Alibrandi); writing-original draft preparation, C.M., D.P., A.M., L.M. and L.C.; writing-review and editing, C.M., L.C., A.A. (Alessio Asmundo), D.P. and A.M.; visualization, D.P., A.M., L.M. and V.M.; supervision, E.V.S., A.M. and D.P.

Funding: This research did not receive any specific grant from funding agencies in the public, commercial, or not-for-profit sectors.

Conflicts of Interest: The authors declare no conflict of interest.

\section{References}

1. Goldstein, D.S. Adrenal responses to stress. Cell. Mol. Neurobiol. 2010, 30, 1433-1440. [CrossRef] [PubMed]

2. Zhang, D.; Ma, Q.Y.; Hu, H.T.; Zhang, M. $\beta 2$-adrenergic antagonists suppress pancreatic cancer cell invasion by inhibiting CREB, NFKB and AP-1. Cancer Biol. Ther. 2010, 10, 19-29. [CrossRef] [PubMed]

3. Goldstein, D.S. Differential responses of components of the autonomic nervous system. Handb. Clin. Neurol. 2013, 117, 13-22. [PubMed]

4. Motzer, S.A.; Hertig, V. Stress, stress response, and health. Nurs. Clin. N. Am 2004, 39, 1-17. [CrossRef] [PubMed]

5. Zhu, B.L.; Ishikawa, T.; Michiue, T.; Li, D.R.; Zhao, D.; Quan, L.; Oritani, S.; Bessho, Y.; Maeda, H. Postmortem serum catecholamine levels in relation to the cause of death. Forensic Sci. Int. 2007, 173, 122-129. [CrossRef] [PubMed]

6. Bańka, K.; Teresiński, G.; Buszewicz, G.; Mądro, R. Glucocorticosteroids as markers of death from hypothermia. Forensic Sci. Int. 2013, 229, 60-65. [CrossRef] [PubMed]

7. Ishikawa, T.; Inamori-Kawamoto, O.; Quan, L.; Michiue, T.; Chen, H.; Wang, Q.; Zhu, B.L.; Maeda, H. Postmortem urinary catecholamine levels with regard to the cause of death. Leg. Med. (Tokyo) 2014, 16, 344-349. [CrossRef]

8. Ishikawa, T.; Quan, L.; Michiue, T.; Kawamoto, O.; Wang, Q.; Chen, J.H.; Zhu, B.L.; Maeda, H. Postmortem catecholamine levels in pericardial and cerebrospinal fluids with regard to the cause of death in medicolegal autopsy. Forensic Sci. Int. 2013, 228, 52-60. [CrossRef]

9. Ishikawa, T.; Yoshida, C.; Michiue, T.; Perdekamp, M.G.; Pollak, S.; Maeda, H. Immunohistochemistry of catecholamines in the hypothalamic-pituitary-adrenal system with special regard to fatal hypothermia and hyperthermia. Leg. Med. (Tokyo) 2010, 12, 121-127. [CrossRef]

10. Aragona, F. L'immagine istologica delle surrenali quale test psicologico postmortale. Riv. Ital. Med. Leg. 1990, 12, 125-138.

11. Belda, X.; Fuentes, S.; Daviu, N.; Nadal, R.; Armario, A. Stress-induced sensitization: The hypothalamicpituitary-adrenal axis and beyond. Stress 2015, 18, 269-279. [CrossRef] [PubMed]

12. Scanzano, A.; Cosentino, M. Adrenergic regulation of innate immunity: A review. Front. Pharmacol. 2015, 6, 171. [CrossRef] [PubMed]

13. Spadari, R.C.; Cavadas, C.; de Carvalho, A.E.T.S.; Ortolani, D.; de Moura, A.L.; Vassalo, P.F. Role of beta-adrenergic receptors and sirtuin signaling in the heart during aging, heart failure, and adaptation to stress. Cell. Mol. Neurobiol. 2018, 38, 109-120. [CrossRef] [PubMed]

14. Shan, T.; Ma, J.; Ma, Q.; Guo, K.; Guo, J.; Li, X.; Li, W.; Liu, J.; Huang, C.; Wang, F.; et al. $\beta 2-A R-H I F-1 \alpha$ : A novel regulatory axis for stress-induced pancreatic tumor growth and angiogenesis. Curr. Mol. Med. 2013, 13, 1023-1034. [CrossRef] [PubMed]

15. Shirasaki, H.; Kanaizumi, E.; Himi, T. Immunohistochemical localization of alpha and beta adrenergic receptors in the human nasal turbinate. Auris Nasus Larynx 2016, 43, 309-314. [CrossRef] [PubMed]

16. Antunes, G.; Simoes de Souza, F.M. Olfactory receptor signaling. Methods Cell Biol. 2016, 132, 127-145. [PubMed]

17. Dixon, R.A.; Kobilka, B.K.; Strader, D.J.; Benovic, J.L.; Dohlman, H.G.; Frielle, T.; Bolanowski, M.A.; Bennett, C.D.; Rands, E.; Diehl, R.E.; et al. Cloning of the gene and cDNA for mammalian beta-adrenergic receptor and homology with rhodopsin. Nature 1986, 321, 75-79. [CrossRef]

18. Emorine, L.J.; Marullo, S.; Briend-Sutren, M.M.; Patey, G.; Tate, K.; Delavier-Klutchko, C.; Strosberg, A.D. Molecular characterization of the human beta 3-adrenergic receptor. Science 1989, 245, 1118-1121. [CrossRef] 
19. Bylund, D.B.; Eikenberg, D.C.; Hieble, J.P.; Langer, S.Z.; Lefkowitz, R.J.; Minneman, K.P.; Molinoff, P.B.; Ruffolo, R.R., Jr.; Trendelenburg, U. International Union of Pharmacology nomenclature of adrenoceptors. Pharmacol. Rev. 1994, 46, 121-136.

20. Daly, C.J.; McGrath, C.J. Previously unsuspected widespread cellular and tissue distribution of $\beta$-adrenoceptors and its relevance to drug action. Trends Pharmacol. Sci. 2011, 32, 219-226. [CrossRef]

21. Cesetti, T.; Hernández-Guijo, J.M.; Baldelli, P.; Carabelli, V.; Carbone, E. Opposite action of beta1- and beta2-adrenergic receptors on $\mathrm{Ca}(\mathrm{V}) 1 \mathrm{~L}$-channel current in rat adrenal chromaffin cells. J. Neurosci. 2003, 23, 73-83. [CrossRef] [PubMed]

22. Cortez, V.; Santana, M.; Marques, A.P.; Mota, A.; Rosmaninho-Salgado, J.; Cavadas, C. Regulation of catecholamine release in human adrenal chromaffin cells by $\beta$-adrenoceptors. Neurochem. Int. 2012, 60, 387-393. [CrossRef] [PubMed]

23. Lightly, E.R.; Walker, S.W.; Bird, I.M.; Williams, B.C. Subclassification of beta-adrenoceptors responsible for steroidogenesis in primary cultures of bovine adrenocortical zona fasciculata/reticularis cells. Br. J. Pharmacol. 1990, 99, 709-712. [CrossRef] [PubMed]

24. Ehrhart-Bornstein, M.; Bornstein, S.R. Cross-talk between adrenal medulla and adrenal cortex in stress. Ann. N. Y. Acad. Sci. 2008, 1148, 112-117. [CrossRef] [PubMed]

25. McRae, A.L.; Saladin, M.E.; Brady, K.T.; Upadhyaya, H.; Back, S.E.; Timmerman, M.E. Stress reactivity: Biological and subjective responses to the cold pressor and Trier Social stressors. Hum. Psychopharmacol. 2006, 21, 377-385. [CrossRef] [PubMed]

26. Holzwarth, M.A.; Cunningham, L.A.; Kleitman, N. The role of adrenal nerves in the regulation of adrenocortical functions. Ann. N. Y. Acad. Sci. 1987, 512, 449-464. [CrossRef]

27. Charlton, B.G.; McGadey, J.; Russell, D.; Neal, D.E. Noradrenergic innervation of the human adrenal cortex as revealed by dopamine-beta-hydroxylase immunohistochemistry. J. Anat. 1992, 180, 501-506.

28. Lowrance, S.A.; Ionadi, A.; McKay, E.; Douglas, X.; Johnson, J.D. Sympathetic nervous system contributes to enhanced corticosterone levels following chronic stress. Psychoneuroendocrinology 2016, 68, 163-170. [CrossRef]

29. Heym, C. Immunocytochemical correlates of an extrapituitary adrenocortical regulation in man. Histol. Histopathol. 1997, 12, 567-581.

30. Ehrhart-Bornstein, M.; Hinson, J.P.; Bornstein, S.R.; Scherbaum, W.A.; Vinson, G.P. Intraadrenal interactions in the regulation of adrenocortical steroidogenesis. Endocr. Rev. 1998, 19, 101-143. [CrossRef]

31. Scheuer, D.A.; Bechtold, A.G. Glucocorticoids modulate baroreflex control of heart rate in conscious normotensive rats. Am. J. Physiol. Regul. Integr. Comp. Physiol. 2002, 282, R475-R483. [CrossRef] [PubMed]

32. Bechtold, A.G.; Scheuer, D.A. Glucocorticoids act in the dorsal hindbrain to modulate baroreflex control of heart rate. Am. J. Physiol. Regul. Integr. Comp. Physiol. 2006, 290, R1003-R1011. [CrossRef] [PubMed]

33. Chandran, D.S.; Ali, N.; Jaryal, A.K.; Jyotsna, V.P.; Deepak, K.K. Decreased autonomic modulation of heart rate and altered cardiac sympathovagal balance in patients with Cushing's syndrome: Role of endogenous hypercortisolism. Neuroendocrinology 2013, 97, 309-317. [CrossRef] [PubMed]

34. Wu, W.C.; Ueng, J.P.; Chai, C.Y. Effects of asphyxia on arterial blood pressure, formation of nitric oxide in medulla and blood parameters in the cat. Chin. J. Physiol. 2005, 48, 51-56. [PubMed]

35. Borovsky, V.; Herman, M.; Dunphy, G.; Caplea, A.; Ely, D. $\mathrm{CO}_{2}$ asphyxia increases plasma norepinephrine in rats via sympathetic nerves. Am. J. Physiol. 1998, 274, 19-22. [CrossRef] [PubMed]

36. Kodikara, S. Attempted suicidal hanging: An uncomplicated recovery. Am. J. Forensic Med. Pathol. 2012, 33, 317-318. [CrossRef] [PubMed]

37. Rybnikova, E.; Glushchenko, T.; Churilova, A.; Pivina, S.; Samoilov, M. Expression of glucocorticoid and mineralocorticoid receptors in hippocampus of rats exposed to various modes of hypobaric hypoxia: Putative role in hypoxic preconditioning. Brain Res. 2011, 1381, 66-77. [CrossRef] [PubMed]

38. Lapchak, P.A.; Chapman, D.F.; Nunez, S.Y.; Zivin, J.A. Dehydroepiandrosterone sulfate is neuroprotective in a reversible spinal cord ischemia model: Possible involvement of GABA(A) receptors. Stroke 2000, 31, 1953-1956. [CrossRef]

39. Lapchak, P.A.; Araujo, D.M. Preclinical development of neurosteroids as neuroprotective agents for the treatment of neurodegenerative diseases. Int. Rev. Neurobiol. 2001, 46, 379-397. 
40. Juhász-Vedres, G.; Rózsa, E.; Rákos, G.; Dobszay, M.B.; Kis, Z.; Wölfling, J.; Toldi, J.; Párducz, A.; Farkas, T. Dehydroepiandrosterone sulfate is neuroprotective when administered either before or after injury in a focal cortical cold lesion model. Endocrinology 2006, 147, 683-686. [CrossRef]

41. Lür, G.; Rákos, G.; Juhász-Vedres, G.; Farkas, T.; Kis, Z.; Toldi, J. Effects of dehydroepiandrosterone sulfate on the evoked cortical activity of controls and of brain-injured rats. Cell. Mol. Neurobiol. 2006, 26, 1505-1519. [CrossRef] [PubMed]

42. Gąsińska, E.; Bujalska-Zadrożny, M.; Sar, M.; Makulska-Nowak, H. Influence of acute and subchronic oral administration of dehydroepiandrosterone (DHEA) on nociceptive threshold in rats. Pharmacol. Rep. 2012, 64, 965-969. [CrossRef]

43. Patte-Mensah, C.; Meyer, L.; Kibaly, C.; Mensah-Nyagan, A.G. Regulatory effect of dehydroepiandrosterone on spinal cord nociceptive function. Front. Biosci. 2010, 2, 1528-1537. [CrossRef]

44. Salgado, D.R.; Rocco, J.R.; Silva, E.; Vincent, J.L. Modulation of the renin-angiotensin-aldosterone system in sepsis: A new therapeutic approach? Expert Opin. Ther. Targets 2010, 14, 11-20. [CrossRef] [PubMed]

45. Moraes, R.B.; Friedman, G.; Viana, M.V.; Tonietto, T.; Saltz, H.; Czepielewski, M.A. Aldosterone secretion in patients with septic shock: A prospective study. Arq. Bras. Endocrinol. Metabol. 2013, 57, 636-641. [CrossRef] [PubMed]

46. Cumming, A.D.; Driedger, A.A.; McDonald, J.W.; Lindsay, R.M.; Solez, K.; Linton, A.L. Vasoactive hormones in the renal response to systemic sepsis. Am. J. Kidney Dis. 1988, 11, 23-32. [CrossRef]

47. Hilgenfeldt, U.; Kienapfel, G.; Kellermann, W.; Schott, R.; Schmidt, M. Renin-angiotensin system in sepsis. Clin. Exp. Hypertens. A 1987, 9, 1493-1504. [CrossRef]

48. Bierens, J.J.; Lunetta, P.; Tipton, M.; Warner, D.S. Physiology of drowning: A review. Physiology (Bethesda) 2016, 31, 147-166. [CrossRef]

49. Conn, A.W.; Miyasaka, K.; Katayama, M.; Fujita, M.; Orima, H.; Barker, G.; Bohn, D. A canine study of cold water drowning in fresh versus salt water. Crit. Care Med. 1995, 23, 2029-2037. [CrossRef]

50. Ventura Spagnolo, E.; Stassi, C.; Mondello, C.; Zerbo, S.; Milone, L.; Argo, A. Forensic microbiology applications: A systematic review. Leg. Med. (Tokyo) 2018, 36, 73-80. [CrossRef]

51. Tsokos, M. Postmortem diagnosis of sepsis. Forensic Sci. Int. 2007, 165, 155-164. [CrossRef]

52. Ventura Spagnolo, E.; Mondello, C.; Di Mauro, D.; Vermiglio, G.; Asmundo, A.; Filippini, E.; Alibrandi, A.; Rizzo, G. Analysis on sarcoglycans expression as markers of septic cardiomyopathy in sepsis-related death. Int. J. Legal Med. 2018, 132, 1685-1692. [CrossRef]

53. Yajima, D.; Inokuchi, G.; Makino, Y.; Motomura, A.; Chiba, F.; Torimitsu, S.; Yamaguchi, R.; Hoshioka, Y.; Malakienė, D.; Raudys, R.; et al. Diagnosis of drowning by summation of sodium, potassium, and chloride ion levels in sphenoidal sinus fluid: Differentiating between freshwater and seawater drowning and its application to brackish water and bathtub deaths. Forensic Sci. Int. 2018, 284, 219-225. [CrossRef]

54. Mondello, C.; Cardia, L.; Ventura-Spagnolo, E. Immunohistochemical detection of early myocardial infarction: A systematic review. Int. J. Leg. Med. 2017, 131, 411-421. [CrossRef]

55. Mondello, C.; Cardia, L.; Bartoloni, G.; Asmundo, A.; Ventura Spagnolo, E. Immunohistochemical study on dystrophin expression in CAD-related sudden cardiac death: A marker of early myocardial ischaemia. Int. J. Leg. Med. 2018, 132, 1333-1339. [CrossRef]

56. Schulze, K.; Ebert, L.C.; Ruder, T.D.; Fliss, B.; Poschmann, S.A.; Gascho, D.; Thali, M.J.; Flach, P.M. The gas bubble sign-a reliable indicator of laryngeal fractures in hanging on post-mortem CT. Br. J. Radiol. 2018, 91, 20170479. [CrossRef]

(C) 2019 by the authors. Licensee MDPI, Basel, Switzerland. This article is an open access article distributed under the terms and conditions of the Creative Commons Attribution (CC BY) license (http://creativecommons.org/licenses/by/4.0/). 